\title{
Life cycle assessment (LCA) of electricity generation technologies: Overview, comparability and limitations
}

\author{
Turconi, Roberto; Boldrin, Alessio; Astrup, Thomas Fruergaard
}

\section{Published in:}

Renewable and Sustainable Energy Reviews

Link to article, DOI:

10.1016/j.rser.2013.08.013

Publication date:

2013

Document Version

Peer reviewed version

Link back to DTU Orbit

Citation (APA):

Turconi, R., Boldrin, A., \& Astrup, T. F. (2013). Life cycle assessment (LCA) of electricity generation technologies: Overview, comparability and limitations. Renewable and Sustainable Energy Reviews, 28, 555565. https://doi.org/10.1016/j.rser.2013.08.013

\section{General rights}

Copyright and moral rights for the publications made accessible in the public portal are retained by the authors and/or other copyright owners and it is a condition of accessing publications that users recognise and abide by the legal requirements associated with these rights.

- Users may download and print one copy of any publication from the public portal for the purpose of private study or research.

- You may not further distribute the material or use it for any profit-making activity or commercial gain

- You may freely distribute the URL identifying the publication in the public portal 
Accepted for publication in Renewable and Sustainable Energy Reviews

\title{
Life cycle assessment (LCA) of electricity generation technologies: overview, comparability and limitations
}

\author{
Roberto Turconi, Alessio Boldrin \& Thomas Astrup \\ Department of Environmental Engineering \\ Technical University of Denmark \\ Kgs. Lyngby, Denmark
}

\begin{abstract}
"NOTE: this is the author's version of a work that was accepted for publication in Renewable and Sustainable Energy Reviews. Changes resulting from the publishing process, such as peer review, editing, corrections, structural formatting, and other quality control mechanisms may not be reflected in this document. Minor changes may have been made to this manuscript since it was accepted for publication. A definitive version is published in Renewable and Sustainable Energy Reviews, vol 28, pp 555-565, doi: dx.doi.org/10.1016/j.rser.2013.08.013"
\end{abstract}




\begin{abstract}
Electricity generation is a key contributor to global emissions of greenhouse gases (GHG), $\mathrm{NO}_{\mathrm{x}}$ and $\mathrm{SO}_{2}$ and their related environmental impact. A critical review of 167 case studies involving the life cycle assessment (LCA) of electricity generation based on hard coal, lignite, natural gas, oil, nuclear, biomass, hydroelectric, solar photovoltaic (PV) and wind was carried out to identify ranges of emission data for $\mathrm{GHG}, \mathrm{NO}_{\mathrm{x}}$ and $\mathrm{SO}_{2}$ related to individual technologies. It was shown that GHG emissions could not be used as a single indicator to represent the environmental performance of a system or technology. Emission data were evaluated with respect to three life cycle phases (fuel provision, plant operation, and infrastructure). Direct emissions from plant operation represented the majority of the life cycle emissions for fossil fuel technologies, whereas fuel provision represented the largest contribution for biomass technologies (71\% for GHG, 54\% for $\mathrm{NO}_{\mathrm{x}}$ and $61 \%$ for $\mathrm{SO}_{2}$ ) and nuclear power (60\% for $\mathrm{GHG}, 82 \%$ for $\mathrm{NO}_{\mathrm{x}}$ and $92 \%$ for $\mathrm{SO}_{2}$ ); infrastructures provided the highest impact for renewables. These data indicated that all three phases should be included for completeness and to avoid problem shifting. The most critical methodological aspects in relation to LCA studies were identified as follows: definition of the functional unit, the LCA method employed (e.g., IOA, PCA and hybrid), the emission allocation principle and/or system boundary expansion. The most important technological aspects were identified as follows: the energy recovery efficiency and the flue gas cleaning system for fossil fuel technologies; the electricity mix used during both the manufacturing and the construction phases for nuclear and renewable technologies; and the type, quality and origin of feedstock, as well as the amount and type of co-products, for biomass-based systems. This review demonstrates that the variability of existing LCA results for electricity generation can give rise to conflicting decisions regarding the environmental consequences of implementing new technologies.
\end{abstract}

Keywords: Life cycleassessment, Electricity generation, Emission factors, Environmental impacts, Emissions 


\section{Introduction}

Between 1990 and 2008, world energy consumption increased by 40\% [1]. Today, 68\% of the energy utilized worldwide originates from fossil fuels (i.e., coal, natural gas and oil), with electricity generation being responsible for $40 \%$ of global $\mathrm{CO}_{2}$ emissions [1]. Emissions of greenhouse gases (GHG), such as $\mathrm{CO}_{2}$ and $\mathrm{CH}_{4}$, from energy generation have been addressed in numerous studies (e.g., [2-8]), which often play a key role in developing GHG mitigation strategies for the energy sector [9]. However, the extent to which these studies provide accurate, robust and comparable information can be questioned with respect to their usefulness for long-term decision-making.

Life cycle assessment (LCA), carbon footprinting and other GHG accounting approaches are commonly used for decision support [10-12]. In LCA, potential environmental impacts associated with the life cycle of a product/service are assessed based on a life cycle inventory (LCI), which includes relevant input/output data and emissions compiled for the system associated with the product/service in question. The comprehensive scope of LCA is useful in avoiding problemshifting from one life cycle phase to another, from one region to another, or from one environmental problem to another [13]. Although a carbon footprint may have more appeal than LCA due to the simplicity of the approach [14], carbon footprints involve only a single indicator, which may result in oversimplification. By optimizing the system performance based only on GHG emissions, new environmental burdens may be introduced from other environmental emissions (e.g., $\mathrm{NO}_{x}$ and $\mathrm{SO}_{2}$ ). A holistic or system-level perspective is therefore essential in the assessment, and the range of emission types included in a study may critically affect the outcome; although described as "full LCA studies", some studies (e.g., [16-18]) include only GHG emissions. Overall emissions can be categorized into direct emissions (e.g., from the stack of a power plant) and indirect emissions (e.g., related either to upstream provision of fuel, resources, goods, etc. or to downstream management of residues and utilization of by-products). Accounting only for direct emissions from electricity generation and failing to include indirect emissions may result in inaccurate conclusions and lead to decisions that do not provide the intended environmental benefits. Previous studies have clearly indicated that indirect GHG emissions from fossil fuels may represent up to $25 \%$ of the overall emissions related to electricity generation [15]; this value is even higher for renewable technologies [8].

Electricity is an essential energy carrier in modern societies, and emission data related to electricity generation are used extensively for accounting and reporting purposes. Datasets and emission factors for electricity generation (e.g., $\mathrm{kg} \mathrm{CO} / \mathrm{MWh}$ ) are used often when performing LCA and/or GHG accounting of products. However, despite the importance of data reliability and the large number of studies that assess electricity generation, significant discrepancies can be found among $\mathrm{LCl}$ datasets for similar electricity technologies. Edenhofer et al. [19] attributed these differences to technology characteristics, local conditions and LCA methodological aspects. Over the past two decades, LCA guidelines (e.g., ISO 14040 [20] and the ILCD handbook [21]) have been developed in an attempt to ensure coherence and comparability among LCA studies. However, these guidelines allow individual researchers to subjectively interpret fundamental methodological aspects (e.g., choice of system boundaries, allocation procedures, and which emissions to include in the assessment). Therefore, a simple statement of compliance accompanying these guidelines is not sufficient to ensure that the results are accurate and robust. Consequently, both $\mathrm{LCl}$ data and LCA results can be misused, whether incidentally or intentionally, when the scope of the original LCA study and the requirements of a user do not coincide [22]. To prevent misuse and unjustified 
decisions, it is thus important that i) methodological choices are described transparently and the scope of the LCA study is narrowly defined and that ii) coherent, appropriate choices are made regarding the system boundaries and $\mathrm{LCl}$ datasets to reduce the gap between the modeled system and reality. Various approaches exist today among LCA practitioners, but the importance of methodological choices, emission types and contributions from individual life cycle phases has not been critically evaluated in the context of electricity generation. A systematic overview of the consequences of methodological choices and technology performance is needed to provide a transparent and balanced foundation for future LCA modeling of electricity technologies.

The objective of this study was to provide a systematic overview of important emissions from electricity generation technologies based on a critical review of relevant LCA studies in the literature. Emission factors for GHG, NOx, and $\mathrm{SO}_{2}$ were selected as key indicators for environmental performance during electricity generation. These emissions were evaluated by i) highlighting important technological differences (e.g., conversion efficiencies and gas cleaning technology) among the assessed technologies, ii) identifying critical methodological choices in LCA studies that affected the results (e.g., system boundaries, functional unit definition and assessment approach), and iii) whenever possible, providing examples illustrating the quantitative importance of these aspects. The intention was to provide a sound basis for selection of data and methodology with respect to LCA modeling of electricity generation.

This paper first provides a critical analysis of the current LCA methodological framework (Section 2), followed by an outline of the selection criteria applied to emissions data and LCA case studies included in the review (Section 3). In Section 4, emission data for electricity generation are evaluated according to the energy source and contributions from fuel provision, plant operation and infrastructure. Section 5 evaluates the importance of key methodological choices and their effect on the results from the LCA studies.

\section{LCA methodology aspects}

The current regulatory framework for LCA is defined by ISO 14040 [20] and ISO 14044 [23]. An LCA study is generally carried out by iterating four phases (goal and scope definition, inventory analysis, impact assessment, interpretation) and is used to quantify major potential environmental impacts related to the product or service in question. LCAs are often applied as decision support tools for selection between different alternatives providing the same product or service. An LCA is quantified by the concept of a "functional unit" that defines the product or service. The functional unit thereby ensures comparability among the alternative scenarios.

Current ISO standards provide guidelines for carrying out an LCA study, but allow freedom for interpretation of key methodological issues [14]. Consequently, subjective choices and approaches may lead to results that are incompatible with other studies having identical goals and scope. When selecting $\mathrm{LCl}$ datasets for electricity production, it is possible to use harmonized data. A meta-analytical harmonization of both technical and methodological aspects of life cycle GHG emissions of energy generation aims to reduce the variability of estimated emission factors and is done by conforming methodological choices (e.g., system boundaries, allocation procedures, and emissions) and technical aspects (e.g., efficiencies and fuel quality). Harmonized emission factors are available for specific technologies: coal [24] (with a focus on the characteristics of the fuel, combustion technology type and thermal efficiency), nuclear energy [25] (with a focus on the primary energy mix, uranium grade and enrichment and the LCA approach), solar PV [26,27] (with a focus on the type of application, meteorological characteristics, performance ratio, lifetime, efficiency and area of the module) and wind energy $[28,29]$ (with a focus on the technology type, capacity, lifetime and capacity factor). However, appropriate $\mathrm{LCl}$ datasets reflecting the local 
conditions and the temporal scope of the study need to be applied, based on the scope of an individual study.

The data acquisition approach itself might significantly affect the results, despite the fact that data should be collected from published sources and should be appropriate to the relevant technologies and processes and that the data selection criteria should be clearly stated [23]. Overall, two approaches are used: process chain analysis (PCA) and input-output analysis (IOA). PCA is a bottom-up approach that uses engineering data and process-specific information preferably obtained directly from the plants. PCA is a time-consuming procedure, but it generally results in more precise results [13]. Data collection in PCA is often simplified by applying cut-off criteria to exclude less relevant processes from the system. This simplification leads, however, to an overall underestimation of the impact [30]. Conversely, IOA is a top-down approach based on monetary data for individual economic sectors, thus considering aggregated flows between sectors. Compared with PCA, IOA provides results that are not only less case-dependent and more complete but also less precise [30,31]. Generally, IOA estimates larger impacts than PCA because the system boundaries are extended, and no process cut-offs are applied [32]. A range of hybrid approaches have been developed to overcome these limitations [33-36]; however, relatively few studies using these approaches are available in the literature. Wiedmann et al. [37] calculated the GHG emissions from wind power using two hybrid approaches as well as PCA and obtained significantly different results, thereby illustrating the variability of results from individual hybrid approaches.

\section{Review selection criteria and approach}

\subsection{Emissions included}

Emissions of GHG, $\mathrm{NO}_{x}$ and $\mathrm{SO}_{2}$ were selected based on their contribution to several critical LCA impact categories and on their importance in decision making and strategic planning. Worldwide, the energy sector contributes $19 \%$ and $56 \%$ of overall $\mathrm{NO}_{x}$ and $\mathrm{SO}_{2}$ emissions [38], respectively, while contributions to GHG emissions amount to $40 \%$ [1]. In addition to $\mathrm{NH}_{3}$, emissions of $\mathrm{NO}_{x}$ and $\mathrm{SO}_{2}$ are largely responsible for acidification $\left(\mathrm{SO}_{2}, \mathrm{NO}_{\mathrm{x}}\right.$ and $\left.\mathrm{NH}_{3}\right)$ and eutrophication $\left(\mathrm{NO}_{\mathrm{x}}\right.$ and $\left.\mathrm{NH}_{3}\right)$. Because $\mathrm{NH}_{3}$ is primarily emitted from animal waste in agriculture [39], $\mathrm{NO}_{\mathrm{x}}$ and $\mathrm{SO}_{2}$ emissions provide a reasonable approximation for contributions to acidification and eutrophication due to electricity generation.

\subsection{LCA case studies included}

This review covered 33 LCA publications including 167 case studies of all main electricity generation technologies, representing $98 \%$ of global electricity generation in 2008 [1,40]. Despite having small shares of the current market, wind power, biomass and solar PV were included in the review because of their high growth rates and the increasing market share that they are likely to achieve in the future. According to the International Energy Agency [40], wind power, biomass and solar PV will constitute $8 \%, 4 \%$ and $2 \%$, respectively, of global electricity generation by 2035 . Table 1 provides an overview of the studies reviewed.

LCA studies were included based on a range of criteria to ensure the best possible data quality and comparability among the studies: 1) the studies included should either separate emissions according to the individual life cycle stage (fuel provision, direct and infrastructure) or include emissions other than GHG, 2) the studies should have a functional unit clearly related to electricity generation (e.g., generation of $1 \mathrm{MWh}$ electricity or similar), and 3 ) the studies should be less than 
15 years old not only to better represent both current and near-future technologies but also to improve comparability in assessment methodologies. Further details regarding the selection criteria are provided in the Supplementary Material.

Table 1. Overview of the technologies considered in the present study.

\begin{tabular}{|c|c|c|c|c|}
\hline Energy source & $\begin{array}{c}\text { Share of global } \\
\text { electricity generation } \\
\text { in } 2008[1,40]\end{array}$ & $\begin{array}{c}\text { Expected share of } \\
\text { global electricity } \\
\text { generation in } 2035 \text { [40] }\end{array}$ & $\begin{array}{l}\text { Number } \\
\text { of case } \\
\text { studies }\end{array}$ & References \\
\hline Hard Coal & $36 \%$ & \multirow[t]{2}{*}{$32 \%$} & 36 & $\begin{array}{c}{[16,41-44,46-48,67} \\
68,78-83]\end{array}$ \\
\hline Lignite & $4.2 \%$ & & 7 & {$[42-44,48,79]$} \\
\hline Natural Gas & $21 \%$ & $21 \%$ & 23 & $\begin{array}{c}{[18,42,43,46-48,52} \\
53,69,78-80,82,84]\end{array}$ \\
\hline Oil & $5.5 \%$ & $1.4 \%$ & 10 & {$[44,46,48,52,53,84]$} \\
\hline Nuclear Power & $13 \%$ & $14 \%$ & 10 & $\begin{array}{c}{[44,46,53,55,78,83,} \\
85-87]\end{array}$ \\
\hline Biomass & $0.8 \%$ & $4.2 \%$ & 25 & {$[46,48,62,67,88-92]$} \\
\hline Hydropower & $16 \%$ & $16 \%$ & 12 & $\begin{array}{c}{[44,46,47,53,62,80,} \\
93-96]\end{array}$ \\
\hline Solar Energy & $0.1 \%$ & $1.8 \%$ & 22 & $\begin{array}{c}{[17,18,44,46,47,53,} \\
55,62,78,80,97] \\
\end{array}$ \\
\hline Wind & $1.1 \%$ & $8.1 \%$ & 22 & $\begin{array}{l}{[44,46-48,53,62,64,} \\
78,80,83,93,98-103]\end{array}$ \\
\hline Others & $1.6 \%$ & $1.9 \%$ & - & \\
\hline Total & $100 \%$ & $100 \%$ & 167 & \\
\hline
\end{tabular}

\section{Results}

In the following sections, the results for electricity generation technologies are evaluated by energy source. For each electricity generation technology, $\mathrm{GHG}$ (labeled $\mathrm{CO}_{2}$-eq.), $\mathrm{NO}_{\mathrm{x}}$ and $\mathrm{SO}_{2}$ emissions were evaluated and categorized according to contributions from the following three life cycle phases: 1) fuel provision (from the extraction of fuel to the gate of the plant), 2) plant operation (operation and maintenance, including residue disposal), and 3) infrastructure (commissioning and decommissioning). Unless otherwise stated, "MWh" hereafter represents the MWh of electricity delivered to the grid.

Of the 167 LCA case studies reviewed (see Table 1 and Table S1-S9 in the Supplementary Material), 102 studies provided GHG data for both fuel provision and plant-related emissions. Infrastructure was mentioned in 89 studies in which commissioning and decommissioning of the physical plant either were included in the accounting or were clearly neglected. Data regarding $\mathrm{NO}_{x}$ and $\mathrm{SO}_{2}$ were available in 102 and 112 studies, respectively, with emissions being distributed between fuel provision and plant emissions in $43\left(\mathrm{NO}_{\mathrm{x}}\right)$ and $41\left(\mathrm{SO}_{2}\right)$ studies. Regarding infrastructure, 27 and 28 studies reported data for $\mathrm{NO}_{\mathrm{x}}$ and $\mathrm{SO}_{2}$, respectively. Out of the 101 studies on thermal electricity generation, 68 reported information on the plant efficiency. Due to the relative paucity of data on $\mathrm{NO}_{\mathrm{x}}$ and $\mathrm{SO}_{2}$ emissions, comparison within and between technologies was not possible in some cases. 
Emission factors for $\mathrm{GHG}\left(\mathrm{CO}_{2}-\mathrm{eq}\right), \mathrm{NO}_{\mathrm{x}}$ and $\mathrm{SO}_{2}$ for the technologies outlined in Table 1 are presented in Figure 1 and Table 2. "Zero" values were reported when it was clearly stated in the study that an emission source was negligible. The robustness and applicability of the reported data are addressed in Section 5.
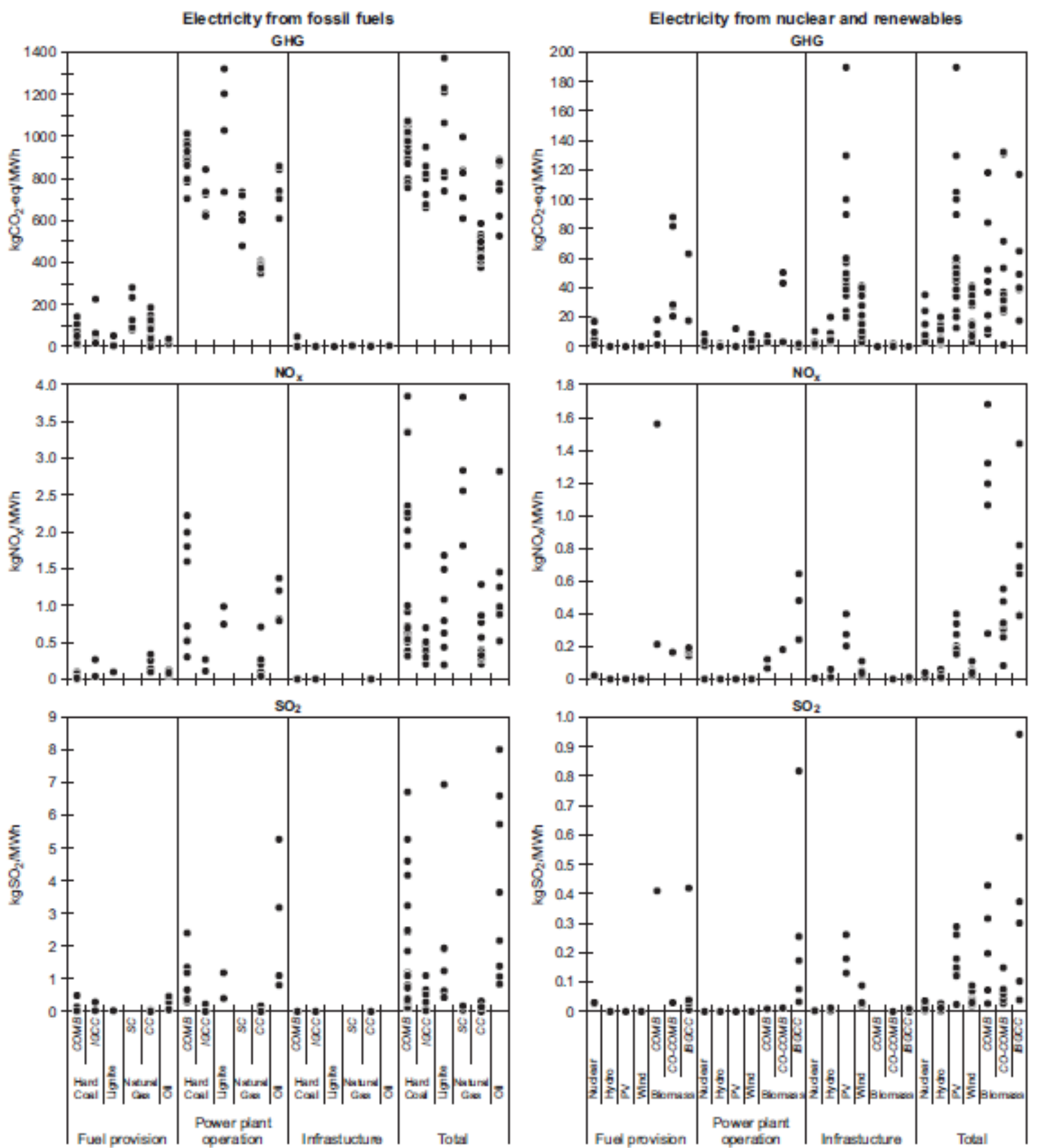

Figure 1. Life cycle emission factors for electricity generation from selected technologies, divided into "fuel provision", "plant operation" and "infrastructure", according to the LCA studies reviewed 
Table 2. Life cycle emission factors for electricity generation from selected technologies. Factors at the top of the table refer to electricity output $\left[\mathrm{kg} / \mathrm{MWh}_{\text {out }}\right]$, while values at the bottom of the table refer to fuel input $\left[\mathrm{kg} / \mathrm{GJ}{ }_{\text {in }}\right]$.

\begin{tabular}{|c|c|c|c|c|}
\hline & Energy source & $\mathrm{CO}_{2}$-eq & $\mathbf{N O}_{\mathrm{x}}$ & $\mathrm{SO}_{2}$ \\
\hline \multirow{9}{*}{ 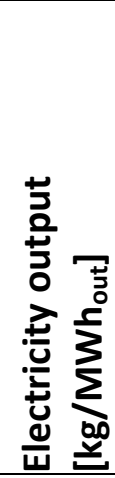 } & Hard Coal & $660-1050$ & $0.3-3.9$ & $0.03-6.7$ \\
\hline & Lignite & $800-1300$ & $0.2-1.7$ & $0.6-7$ \\
\hline & Natural Gas & $380-1000$ & $0.2-3.8$ & $0.01-0.32$ \\
\hline & Oil & $530-900$ & $0.5-1.5$ & $0.85-8$ \\
\hline & Nuclear Power & $3-35$ & $0.01-0.04$ & $0.003-0.038$ \\
\hline & Biomass & $8.5-130$ & $0.08-1.7$ & 0.03-0.94 \\
\hline & Hydropower & $2-20$ & $0.004-0.06$ & $0.001-0.03$ \\
\hline & Solar Energy & $13-190$ & $0.15-0.40$ & $0.12-0.29$ \\
\hline & Wind & $3-41$ & $0.02-0.11$ & $0.02-0.09$ \\
\hline \multirow{5}{*}{ 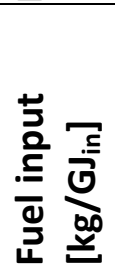 } & Hard Coal & $46-125$ & $0.028-0.352$ & $0.003-0.596$ \\
\hline & Lignite & $91-141$ & $0.025-0.161$ & $0.047-0.753$ \\
\hline & Natural Gas & $57-85$ & $0.037-0.277$ & $0.0002-0.044$ \\
\hline & Oil & $75-94$ & $0.081-0.298$ & $0.112-0.698$ \\
\hline & Biomass & $0.1-10$ & $0.007-0.128$ & $0.004-0.094$ \\
\hline
\end{tabular}

\subsection{Hard Coal}

Thirty-six studies involving electricity generation from coal were included based on the selection criteria. For all three compounds studied, most of the emissions were related to the operation of the power plant. Life cycle GHG emissions were accounted for in all 28 studies on combustion; 11 studies distinguished between fuel-related and plant-related emissions, whereas only 6 studies either reported data for the infrastructure or stated clearly that this aspect was neglected. Data for $\mathrm{NO}_{\mathrm{x}}$ and $\mathrm{SO}_{2}$ were found in 17 and 19 studies, respectively, and out of these, 9 and 7 studies, respectively, provided data for fuel provision separately from direct emissions of $\mathrm{NO}_{\mathrm{x}}$ and $\mathrm{SO}_{2}$. All 8 studies concerning gasification provided data on GHG emissions, with 6 including separate data for fuel provision and direct emissions. Emission factors for $\mathrm{NO}_{\mathrm{x}}$ and $\mathrm{SO}_{2}$ were provided in 6 studies, 2 of which identified contributions from fuel provision and power plant operation.

The results showed that direct emissions represented the main contribution for GHG emissions from coal-based technologies. The key factors were found to be the type of technology and the process efficiency. For example, GHG emission factors for direct combustion (DC) were in the range of $750-1050 \mathrm{~kg} \mathrm{CO}$-eq/ $\mathrm{MWh}$ for which the lowest and highest values corresponded to energy recovery efficiencies of $42 \%$ and $33 \%$, respectively [41-43], calculated relative to the input energy. On the other hand, coal gasification (IGCC) could achieve higher efficiencies (up to 52\%), thus leading to lower GHG emission factors compared to direct combustion $\left(660-800 \mathrm{~kg} \mathrm{CO}_{2^{-}}\right.$ eq/MWh). These values were in agreement with previous review studies in which overall emission factors on the order of $800-1200 \mathrm{~kg} \mathrm{CO}$-eq/MWh were reported for electricity generation from hard coal $[3,8,15,44-46]$.

Data for $\mathrm{NO}_{x}$ and $\mathrm{SO}_{2}$ emissions from direct combustion showed large amounts of variability among individual studies, with a flue gas cleaning (FGC) system and the energy recovery efficiency being the two most important aspects affecting the magnitude of emission factors. Emissions on the order of 2-4 $\mathrm{kg} \mathrm{NO}_{x} / \mathrm{MWh}$ and 2-7 $\mathrm{kg} \mathrm{SO}_{2} / \mathrm{MWh}$ throughout the life cycle were typically found for old power plants equipped with no or low-tech FGC systems, whereas modern plants had 
emission factors one order of magnitude lower (0.3-1 kg NO$/ \mathrm{MWh}$ and 0.1-1 kg SO$/ \mathrm{MWh}$ ). For coal gasification, overall emission factors were found on the order of 0.2-0.7 kg NO$/ \mathrm{MWh}_{\mathrm{x}}$ and 0.1-1 $\mathrm{kg} \mathrm{SO}_{2} / \mathrm{MWh}$, with the process efficiency and an FGC system being the key aspects.

Coal provision accounted for $0.9 \%$ to $2.6 \%$ of the overall GHG emissions from coal-based electricity generation, mainly as a consequence of methane emissions during mining [3]. Emissions of $\mathrm{NO}_{\mathrm{x}}$ and $\mathrm{SO}_{2}$ were dominated by direct emissions for coal combustion, whereas fuel provision was more relevant for IGCC, due to the high efficiency and high removal via FGC and consequently lower emissions at the stack. For example, Nomura [47] and the DoE [48] reported emissions for coal provision contributing to more than half of the overall impacts for $\mathrm{NO}_{x}$ and $\mathrm{SO}_{2}$, respectively for IGCC; infrastructure was always found to be negligible for all three compounds.

\subsection{Lignite}

Seven studies involving lignite were found to be relevant. All studies reported emissions for all three compounds, but only 4 studies for $\mathrm{GHG}$ and 2 studies for $\mathrm{NO}_{\mathrm{x}} / \mathrm{SO}_{2}$ specified emissions according to the individual life cycle phases. The results showed that emissions from lignite provision are much lower than those from hard coal, mainly because of the shorter transportation distances involved. Lignite power plants are, in fact, often placed close to mines due to the large amount of material involved and to the cost of transportation [3]. Lower amounts of methane were emitted during mining activity compared with hard coal, representing $0.6 \%$ of life cycle GHG emissions [8]. Emissions related to infrastructure were found to be negligible for all three compounds.

Life cycle GHG emissions varied due to the lower heating value of the lignite and to the efficiency of energy recovery. Emission factors were in the range of 800-1300 kg CO values related to a gasification process with high efficiency (52\%). Concerning the energy content of the fuel, the lower the heating value of the fuel, the higher the GHG emission factor [8]. In some cases, this trend can be more important than the energy efficiency of the plant. For example, in the ExternE study [49], a system using fuel with a heating value of $5.4 \mathrm{MJ} / \mathrm{kg}$ and having an energy efficiency of 37\% was considered, whereas May [42,43] reported a heating value of $9 \mathrm{MJ} / \mathrm{kg}$ and an efficiency of $27 \%$. These two studies reported direct GHG emissions from plants of approximately 1320 and $1200 \mathrm{~kg} \mathrm{CO}$-eq/MWh, with the lower efficiency process having lower direct GHG emissions. These values were in agreement with previous studies, thus providing an overall range for lignite technologies of 900-1300 kg CO 2 -eq/MWh [3,8,15,44-46].

Similar to hard coal emissions, $\mathrm{NO}_{\mathrm{x}}$ and $\mathrm{SO}_{2}$ emissions showed large variations (of up to one order of magnitude) among the studies reviewed, with results being largely affected by the energy efficiency and the FGC systems. Emission factors were within the range of 1.1-1.7 $\mathrm{kg} \mathrm{NO} \times \mathrm{MWh}$ and 1.2-7 kg SO $2 / \mathrm{MWh}$ for older and less efficient (27-40\%) power plants either with outdated or without FGC systems, whereas more efficient (over 40\%) power plants with modern FGC systems had emission factors of 0.2-0.8 $\mathrm{kg} \mathrm{NO}_{x} / \mathrm{MWh}$ and 0.4-0.6 $\mathrm{kg} \mathrm{SO}_{2} / \mathrm{MWh}$.

\subsection{Natural Gas}

Two technologies for electricity generation based on natural gas were considered: a single cycle (SC) turbine with low energy efficiencies (26-35\%) and a combined cycle (CC) turbine with high energy efficiencies (up to 60\%). This distinction was made because the first technology provides peak electricity (i.e., electricity produced to cover peaks in electricity demand), whereas the latter delivers baseload power. All 23 LCA studies reviewed reported factors for GHG emissions, 20 of 
which also specified contributions from different life cycle phases. Seventeen and sixteen studies reported overall emissions of $\mathrm{NO}_{x}$ and $\mathrm{SO}_{2}$, respectively, whereas 7 and 6 studies also identified contributions from $\mathrm{NO}_{x}$ and $\mathrm{SO}_{2}$, respectively, within the life cycle phases (only CC technologies). Direct GHG emissions from CC plants were rather consistent among different studies (350-410 kg $\mathrm{CO}_{2}$-eq/MWh), with fuel provision contributing relatively large additional impacts $\left(10-180 \mathrm{~kg} \mathrm{CO} 2^{-}\right.$ eq/MWh). Fuel provision represented up to $30 \%$ of the overall GHG emissions, mainly due to fugitive methane emissions and energy consumption during gas extraction and transportation. LCA studies commonly assume that $1-2 \%$ of gross natural gas is lost to the atmosphere as fugitive emissions during extraction [50]. Furthermore, up to $10 \%$ of the natural gas extracted is consumed to power fuel extraction and transportation [48]. Liquefied natural gas has even higher emissions due to the liquefaction process itself and to the longer transportation distances ( 6 out of 8 studies reported emissions above $100 \mathrm{~kg} \mathrm{CO}$-eq/MWh for fuel provision). Single cycle plants produced higher and more variable direct emissions at the power plant (480-730 $\mathrm{kg} \mathrm{CO}_{2}$-eq/MWh) compared with CC plants, and consequently, also over the life cycle (610-850 kg $\left.\mathrm{CO}_{2}-\mathrm{eq} / \mathrm{MWh}\right)$. These values were in agreement with previous studies estimating approximately $400-900 \mathrm{~kg} \mathrm{CO}$ - $^{-}$ eq/MWh for electricity generation from natural gas [3,8,15,44-46].

For CC plants, overall $\mathrm{NO}_{\mathrm{x}}$ emissions were on the order of $0.2-1.3 \mathrm{~kg} \mathrm{NO}$ 侻 $/ \mathrm{MWh}$, with fuel provision (0.1-0.5 kg/MWh) playing an important role as a consequence of the energy used for extraction of natural gas [51]. Compared to CC plants, emissions of $\mathrm{NO}_{\mathrm{x}}$ from SC plants were much higher, approximately 1.8-3.8 kg NO$/ \mathrm{MWh}$ : lower efficiencies and less efficient FGC systems were responsible for this difference. Emissions of $\mathrm{SO}_{2}$ were similar for the two technologies, in the range of $0.01-0.32 \mathrm{~kg} / \mathrm{MWh}$. The data available for CC studies show that natural gas provision can contribute up to $80-90 \%$ of the life cycle emissions of $\mathrm{SO}_{2}$. None of the studies provided data for $\mathrm{NO}_{\mathrm{x}}$ and $\mathrm{SO}_{2}$ with respect to the commissioning and decommissioning of natural gas power plants.

\subsection{Oil}

Ten studies included GHG emissions for electricity generation from oil, 5 studies identified contributions related to the individual life cycle phases. Emissions of $\mathrm{NO}_{x}$ and $\mathrm{SO}_{2}$ were considered in 7 and 8 studies, respectively, with 4 of them specifying the contributions throughout the life cycle for both emissions.

The results showed that $\mathrm{GHG}$ and $\mathrm{NO}_{\mathrm{x}}$ emissions were mainly related to power plant operation, whereas fuel provision (exploration, extraction, refinery and transportation) represented up to $20 \%$ of the $\mathrm{SO}_{2}$ emissions occurring throughout the life cycle [52], which depends on the FGC system, the oil provision and the sulfur content of the fuel. The energy recovery efficiency is the key parameter for GHG emissions: in base load power plants, efficiencies can reach 58\%, corresponding to $530 \mathrm{~kg} \mathrm{CO}$-eq/MWh emitted throughout the life cycle. Conversely, peak load power plants have lower efficiencies (i.e., 30-40\%), with subsequent GHG emission factors between 750 and $900 \mathrm{~kg} \mathrm{CO}_{2}$-eq/MWh over the entire life cycle.

Emission factors for $\mathrm{NO}_{x}$ were in the range of $0.5-1.5 \mathrm{~kg} / \mathrm{MWh}$, mainly depending on the $\mathrm{FGC}$ system of the plant. In particular, emission factors varied from $0.8 \mathrm{~kg} / \mathrm{MWh}$ for modern plants to up to 6-8 $\mathrm{kg} / \mathrm{MWh}$ for old plants not equipped with $\mathrm{SO}_{2}$ scrubbing systems. Data about the commissioning and decommissioning of oil power plants were quite limited, with only a single study reporting a contribution from infrastructure of $2.2 \mathrm{~kg} \mathrm{CO}$-eq/MWh [53]. Such a contribution can be considered negligible compared to those from direct emissions. 


\subsection{Nuclear power}

Nuclear power was included in 10 of the reviewed studies. All studies reported GHG emission factors, and 7 identified contributions from individual life cycle stages. Emissions of $\mathrm{NO}_{\mathrm{x}}$ and $\mathrm{SO}_{2}$ were reported in 4 and 5 studies, respectively; contributions throughout the life cycle were identified in 2 of these studies.

The results showed that GHG emission factors varied greatly, with differences of up to one order of magnitude (i.e., $3.1-35 \mathrm{~kg} \mathrm{CO}$-eq/MWh). This variability was due both to the different technologies and to the methodological approaches used to assess them. In particular, the assumptions regarding the inclusion of uranium enrichment processes had a significant influence on the results. The gas diffusion method, for example, uses approximately 40 times more electricity than the gas centrifuge method $[33,54]$. These processes, combined with the use of fossil fuel-based electricity, can explain the wide range of values found for fuel provision (1.5-18 $\mathrm{kg}$ $\mathrm{CO}_{2}$-eq/MWh).

When using IOA, emission factors were estimated as being 10-20 times larger than those calculated using PCA [55]. For example, Sovacool [56] provided a detailed review of 103 studies on nuclear power, which estimated an IOA-based emission factor for nuclear-based electricity generation of $66 \mathrm{~kg} \mathrm{CO}$-eq/MWh shared almost equally among the three life cycle phases, whereas Dones and colleagues [3] estimated an electricity generation of 2-77 kg $\mathrm{CO}_{2}$-eq/MWh. The difference between the IOA and PCA results arises from the respective capabilities of the two approaches to properly model the great complexity of the system studied. Further discussion of the topic can be found in the discussion section.

Emissions of $\mathrm{NO}_{x}$ and $\mathrm{SO}_{2}$ related to electricity generation from nuclear power were mainly due to energy consumption during uranium extraction and enrichment. Emission factors were in the range of 0.01-0.04 kg/MWh for $\mathrm{NO}_{x}$ and $0.003-0.038 \mathrm{~kg} / \mathrm{MWh}$ for $\mathrm{SO}_{2}$, depending on the input electricity mix. Emissions related to infrastructure were found to be relevant for GHG (20-30\% of the total), while being almost insignificant for both $\mathrm{NO}_{x}$ and $\mathrm{SO}_{2}$.

\subsection{Hydropower}

Hydropower encompasses solutions such as dams with reservoir and run-of-river plants. The first solution requires a dam to create a basin, and thus allows for matching peaks in electricity demand. Electricity generation from run-of-river systems depends on the amount of water flow and cannot be controlled. None of the reviewed studies made quantitative considerations regarding the secondary utilization of water for drinking, irrigation and navigation purposes.

For hydropower, 12 studies were included: 5 systems with dam-reservoirs and 7 run-of-river plants. Emission factors for GHG were reported in all studies, whereas emission factors for $\mathrm{NO}_{\mathrm{x}}$ and $\mathrm{SO}_{2}$ were only included in 6 and 9 studies, respectively. Most emissions were generally linked to the infrastructure. Life cycle emissions of $\mathrm{GHG}$ were reported in the range of $2-5 \mathrm{~kg} \mathrm{CO} 2^{-}$ eq/MWh for run-of-river systems and $11-20 \mathrm{~kg} \mathrm{CO}$-eq/MWh for dam-reservoirs. The highest emissions factors were found in a study using the IOA approach [47], again indicating that greater impacts are estimated when using IOA instead of PCA. An important aspect of hydropower with dam-reservoirs is methane emissions from the anaerobic decomposition of flooded organic matter. These emissions depend on the local climate, reservoir size, water depth, type and amount of flooded vegetation and soil type; thus, large variations in emission factors can be seen. For example, emission factors range from $0.35 \mathrm{~kg} \mathrm{CO} 2^{-} \mathrm{eq} / \mathrm{MWh}$ for alpine regions to $30 \mathrm{~kg} \mathrm{CO}_{2-}$ eq/MWh in Finland and reach up to $340 \mathrm{~kg} \mathrm{CO}$-eq/MWh in Brazil $[3,8,57]$. Emission factors 
reported in previous review studies were in the range of 2-40 $\mathrm{kg} \mathrm{CO}$-eq/ $\mathrm{MWh}[3,4,8,15,44-$ $46,53,58-60]$, but higher values were found when the reservoirs were located in tropical areas.

Emission factors for $\mathrm{NO}_{x}$ and $\mathrm{SO}_{2}$ were found in the range of 0.004-0.06 kg NO$/ \mathrm{MWh}$ and 0.004$0.03 \mathrm{~kg} \mathrm{SO}_{2} / \mathrm{MWh}$, respectively. Emissions of $\mathrm{NO}_{\mathrm{x}}$ and $\mathrm{SO}_{2}$ were mainly associated with dam construction (i.e., provision of materials) and are therefore related to the dam size and generation capacity.

\subsection{Solar photovoltaic (PV)}

All 22 LCA studies reviewed on solar PV included GHG data, specified for individual phases of the life cycle. All studies except for one related all emissions to the infrastructure, in particular to the manufacturing of solar cells, while neglecting the impact from maintenance. Emissions of $\mathrm{NO}_{\mathrm{x}}$ and $\mathrm{SO}_{2}$ were considered in 6 and 7 studies, respectively.

Emission factors for GHG showed high variability (one order of magnitude, $13-130 \mathrm{~kg} \mathrm{CO}_{2}$ eq/MWh), mainly due to local conditions, such as the source of the electricity used during manufacturing, the typology of panels and the climate conditions where the panels were installed $[55,61]$. One study [62] showed how GHG emissions of PV technology produced in different countries would differ from each other because of the electricity input to the manufacturing process. A similar occurrence can be explained for $\mathrm{NO}_{x}$ and $\mathrm{SO}_{2}$ emissions. For example, emission factors range from $0.15-0.18 \mathrm{~kg} \mathrm{NO} / \mathrm{MWh}$ and $0.12-0.15 \mathrm{~kg} \mathrm{SO}_{2} / \mathrm{MWh}$ in southern Europe [44] to $0.34 \mathrm{~kg} \mathrm{NO} / \mathrm{MWh}$ and $0.29 \mathrm{~kg} \mathrm{SO} / \mathrm{MWh}$ in Germany [63], for $\mathrm{NO}_{\mathrm{x}}$ and $\mathrm{SO}_{2}$ emissions, respectively. Using IOA, Nomura [47] estimated emission factors in the range of $100-190 \mathrm{~kg} \mathrm{CO}_{2^{-}}$ eq/MWh, 0.20-0.40 kg NO$/ \mathrm{MWh}$ and 0.13-0.26 kg SO$/ \mathrm{MWh}$. These emissions are slightly higher than those estimated using PCA, but the significant differences between IOA and PCA results that had previously been highlighted for nuclear energy were not observed in this case. Emission factors reported in previous studies were in the range of 40-160 kg $\mathrm{CO}_{2}$-eq/ $\mathrm{MWh}[3,4,8,15,44-$ $46,53,58,59,64,65]$.

\subsection{Wind}

Of the 22 selected LCA studies, 20 attributed all emissions entirely to the infrastructure. Emission factors for GHG were found in the range of 3-28 $\mathrm{kg} \mathrm{CO}_{2}$-eq/MWh for PCA studies with system boundaries limited to wind turbines. In this case, the main contributions were related to material provision and construction of the wind turbines. Hence, the local electricity mix where manufacturing and installation of the turbines occurred had a significant influence on the results $[33,66]$. Onshore and offshore turbines can have similar emission factors because larger emissions during the construction phase can be compensated for by the higher productivity of offshore turbines [63]. One study [67] accounted for GHG emissions, including an electricity storage device (i.e., hydrogen for fuel cells) that obtained higher overall emission factors (35-41 kg CO $2-e q / M W h)$. It should be noted, however, that such a study including electricity storage cannot be directly compared to a study of wind power without storage because of the different functional unit used (see the discussion later). Based on IOA, emission factors were estimated on the order of 30-40 kg $\mathrm{CO}_{2}$-eq/MWh [47], thus providing higher values than similar studies using PCA. Emission factors reported in previous review studies were in the range of $5-35 \mathrm{~kg} \mathrm{CO}$-eq/ $\mathrm{MWh}[3,4,8,15,44-$ 46,53,58-60,68].

Most LCA studies provided emission factors for $\mathrm{NO}_{x}$ and $\mathrm{SO}_{2}$, ranging from 0.02-0.06 kg NO$/ \mathrm{MWh}$ and 0.02-0.04 $\mathrm{kg} \mathrm{SO}_{2} / \mathrm{MWh}$ with emissions mainly depending on the electricity mix used for 
manufacturing. When using IOA, emission factors of $0.11 \mathrm{~kg} \mathrm{NO} / \mathrm{MWh}$ and $0.05 \mathrm{~kg} \mathrm{SO} / \mathrm{MWh}$ were reported [47], which were higher than the previously mentioned emission factors estimated using PCA.

\subsection{Biomass}

Nineteen studies, including three types of biomass-based technologies, were addressed: cocombustion (CO-COMB) with a fossil fuel, direct combustion (COMB) and gasification (IBGCC). All reviewed studies reported GHG emission factors, while 14 also considered $\mathrm{NO}_{\mathrm{x}}$ and $\mathrm{SO}_{2}$ emissions. Contributions from individual life cycle phases for all three compounds were provided in only 8 studies. In studies assessing residual biomass, all impacts were associated with power plant operation, i.e., assuming a "zero burden" boundary upstream of the plant (see the discussion regarding this aspect). Emissions related to infrastructures were negligible for all three compounds.

The reported GHG emission factors showed high variability: $25-130 \mathrm{~kg} \mathrm{CO}$-eq/MWh (CO-COMB), 8.5-118 kg CO $2-e q / \mathrm{MWh}$ (COMB) and 17-117 kg CO -eq/MWh (IBGCC). These data do not include biogenic $\mathrm{CO}_{2}$ emissions because it is common LCA practice to assume a global warming characterization factor for biogenic $\mathrm{CO}_{2}$ of zero [69]. However, when emission factors are used for GHG emission reporting within the IPCC framework, biogenic $\mathrm{CO}_{2}$ is then included because the $\mathrm{CO}_{2}$ uptake by biomass is accounted for within the AFOLU (i.e., Agriculture, Forestry, and Other Land Use) sector [70].

Emission factors for $\mathrm{NO}_{\mathrm{x}}$ were in the range of 0.08-1.7 $\mathrm{kg} \mathrm{NO} / \mathrm{MWh}$, with the highest values related to $C O M B$ and the lowest values associated with CO-COMB. In addition to the FGC system, $\mathrm{NO}_{\mathrm{x}}$ emissions were strongly related to the type of biomass. In the provision phase, emissions occurred from the use of machinery during cultivation and harvesting in the case of energy crops, whereas no emissions were typically associated with wood residues (adopting a zero burden approach). Combustion of furniture wood residues may result in larger emissions due to the nitrogen content of the fuel [71]. Emissions of $\mathrm{SO}_{2}$ also showed high variability for all three technologies assessed, ranging from 0.03 to $0.94 \mathrm{~kg} \mathrm{SO}_{2} / \mathrm{MWh}$, with the largest contribution from fuel provision.

\section{Discussion}

In the following sections, critical methodological aspects influencing the results of the LCA case studies discussed in the previous section are identified and evaluated. To the extent that data availability permits, the aspects identified are quantitatively evaluated. Suggestions are provided for consistent comparisons between individual technologies and for the criteria for data selection in LCA studies.

\subsection{Emission selection}

Of the 167 case studies reviewed, 101 assessed emissions of all three compounds: GHG, NO ${ }_{x}$ and $\mathrm{SO}_{2}$. Although $\mathrm{GHG}$ emissions are an adequate indicator of the environmental performance regarding global warming, other environmental impacts should also be considered. For example, Table 2 shows that natural gas and oil have similar GHG emission factors $\left(380-1000 \mathrm{~kg} \mathrm{CO}\right.$ - $^{-}$ eq/MWh and 530-900 kg CO $2-e q / M W h)$, but that $\mathrm{SO}_{2}$ emissions from oil $(0.85-8 \mathrm{~kg} / \mathrm{MWh})$ are more than one order of magnitude larger than those from natural gas $(0.01-0.32 \mathrm{~kg} / \mathrm{MWh})$. Similarly, biomass and solar PV emit $13-190 \mathrm{~kg} \mathrm{CO}$-eq/MWh and 8.5-130 kg $\mathrm{CO}_{2}$-eq/MWh, 
respectively, but emissions of $\mathrm{NO}_{\mathrm{x}}$ are much larger from biomass (0.08-1.7 $\mathrm{kg} / \mathrm{MWh}$ ) than from solar PV (0.15-0.40 kg/MWh). In both cases, an assessment focused only on global warming would give similar results between the two technologies, while the consequences for the eutrophication and acidification impact categories would be different.

The relevance of considering emissions other than GHG can be further explained by considering the distribution of emissions over the life cycle of electricity generation. Only 39 studies provided $\mathrm{NO}_{\mathrm{x}}$ and $\mathrm{SO}_{2}$ emission data disaggregated according to the individual life cycle stage, and while GHG emissions may be appropriate for identifying the major sources of impact over the life cycle for hard coal, lignite, oil, hydro, solar PV and wind, GHG emissions are not an appropriate indicator for other technologies. Fuel provision is the main factor responsible for GHG emissions for biomass (71\%), while direct emissions dominate $\mathrm{NO}_{\mathrm{x}}$ and $\mathrm{SO}_{2}$ emissions (54\% and 61\%, respectively); emissions are distributed over the life cycle for nuclear power (approximately $60 \%$ fuel provision, $20 \%$ direct emissions and $20 \%$ infrastructures), whereas fuel provision dominates emissions of $\mathrm{NO}_{\mathrm{x}}(82 \%)$ and $\mathrm{SO}_{2}(92 \%)$. Direct emissions at the plant represent $83 \%$ of the total GHG emissions for natural gas, whereas fuel provision is responsible for $54 \%$ and $96 \%$ of $\mathrm{NO}_{\mathrm{x}}$ and $\mathrm{SO}_{2}$ emissions, respectively. These data illustrate that an isolated focus on $\mathrm{GHG}$ emissions can lead to incorrect conclusions concerning the environmental consequences of electricity generation technologies. As documented in this review, emissions data for other important impact categories are in fact available and should be included in assessments.

\subsection{Technological, geographical and temporal scope}

It was found that energy efficiency and a FGC system were the two most important factors for fossil-fuel-based technologies. Figure 2 shows that, for different fuels, direct GHG emissions are directly correlated to the energy recovery efficiency of the plant. A similar correlation could not be found for either $\mathrm{NO}_{\mathrm{x}}$ or $\mathrm{SO}_{2}$ (see Figure $\mathrm{S} 1$ in Supplementary Material) because, in addition to the energy recovery efficiency, $\mathrm{NO}_{\mathrm{x}}$ emissions are also influenced by the $\mathrm{FGC}$ system, whereas $\mathrm{SO}_{2}$ emissions are affected by both the $\mathrm{FGC}$ system and fuel quality. A correlation between the $\mathrm{NO}_{\mathrm{x}}$ and $\mathrm{SO}_{2}$ emissions and time (using the publication date as a proxy when more specific data were not available) was attempted, but no apparent correlation was identified. Most likely, the publication date of the studies did not necessarily reflect the age of the power plants assessed. This lack of data highlights the importance of thoroughly reporting all available details about the facility under assessment (including the period of operation). The selection of inappropriate datasets not sufficiently reflecting the real system in focus may clearly result in a significant underor overestimation of emissions. The range of emission data reported in Figure 1 represents various technological, geographical and temporal scopes of the underlying LCA studies. Inappropriate use of the results or the emission data from the studies in new LCAs may significantly affect the results.

For nuclear and renewable electricity systems, the reference year and the geographical origin of the materials and energy used for the infrastructure should be carefully identified because the local conditions and the geographical, temporal and technological quality of the data could significantly influence the results. Krauter [62] calculated GHG emissions one order of magnitude lower for Brazil than for Germany for the production of the same PV system in 2003, due to the cleaner Brazilian electricity mix (with an emission factor of $70 \mathrm{~kg} \mathrm{CO}$-eq/MWh) compared with the German mix (530 kg CO 2 -eq/MWh). Furthermore, rapidly growing technologies such as wind or solar PV are subject to constant development [19], meaning that recent and up-to-date $\mathrm{LCl}$ data 
should be used to obtain consistent and realistic results. As mentioned in Section 2, a harmonization of technical parameters is available for LCA of nuclear power [25], solar PV [26,27] and wind power $[28,29]$.

\subsection{Contributions from upstream impacts}

The results indicate that it is important to correctly set the system boundaries to avoid the undesired cut-off of a relevant part of the emissions. Although direct emissions represented 83$99 \%$ of the total GHG emissions from electricity generation based on fossil fuels, they were less relevant for other systems (i.e., nuclear power plants and renewables). Upstream processes potentially having relevant impacts include fuel provision and the commissioning and decommissioning of plants. Few authors consider fuel provision negligible with regards to GHG emissions (e.g., [67]), while others depict it as important (e.g., [16,42,43,53,72,73]), in particular for emissions other than GHG. For example, based on the data in Figure 1, fuel provision accounts for on average $71 \%$ and $60 \%$ of the GHG emissions estimated for biomass and nuclear power plants, respectively. Fuel provision for biomass-based electricity is discussed further in Section 5.4. Infrastructure was considered a minor issue in several studies concerning electricity generation from fossil fuels, while it was found to be more relevant (in some cases dominant) for renewable technologies and nuclear power plants. For example, the reviewed studies showed that infrastructure accounts for on average $22 \%$ of the overall GHG emissions from nuclear power plants, while it represents the nearly exclusive burden (97-99\% of total emissions) for hydropower, PV and wind systems (Figure 1).

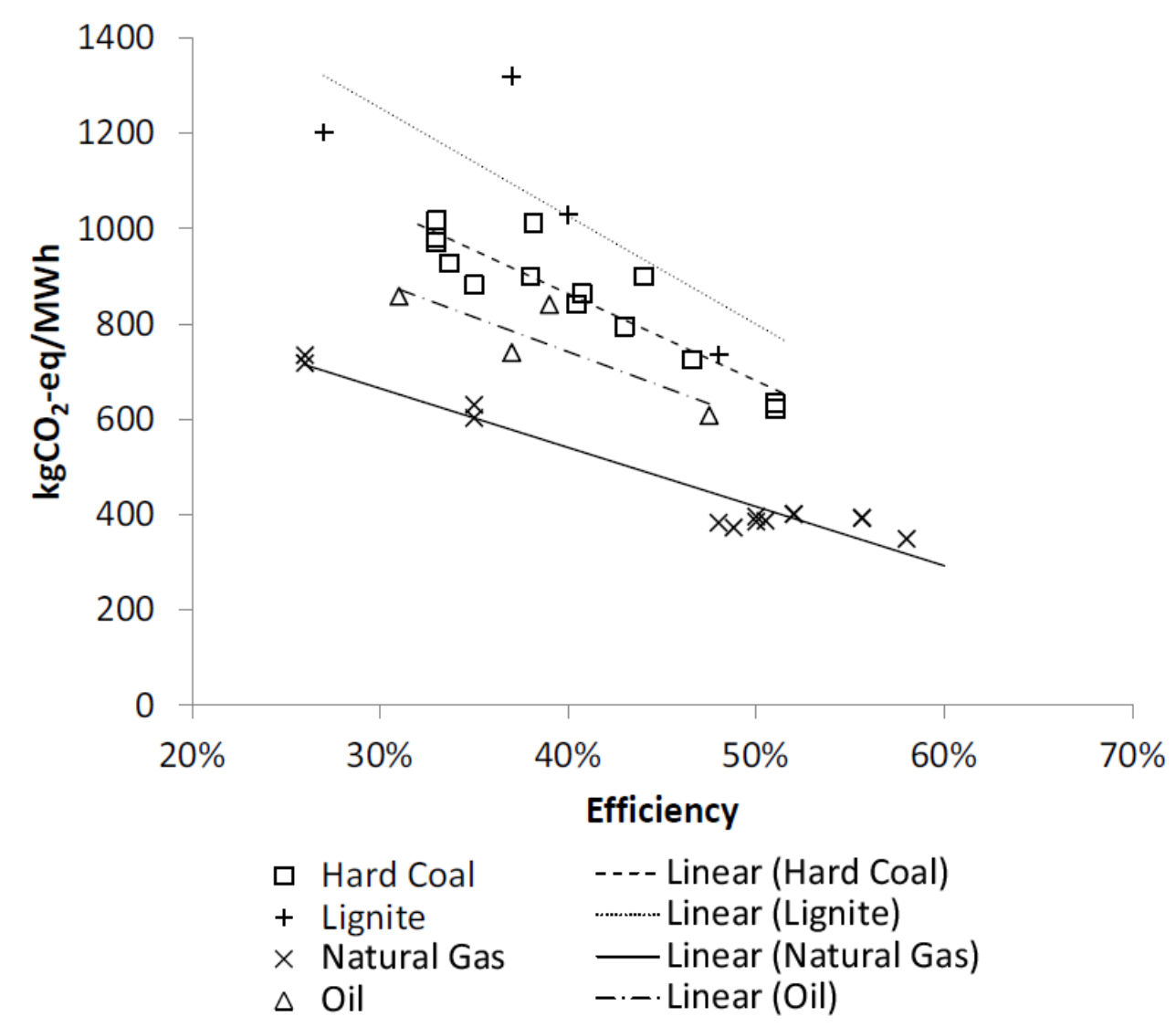

Figure 2. Relationship between plant efficiency and GHG direct emissions for hard coal, lignite, natural gas and oil 


\subsection{Provision of biomass}

Some studies ( 6 of 25 in this article) involving biomass-based electricity generation apply a zeroburden assumption, i.e., neglecting any upstream impacts associated with the biomass. While this approach may appear justifiable when focusing on residual biomass resources traditionally not exploited for energy purposes (i.e., remaining on agricultural land or used for animal feeding and/or bedding), such an assumption is questionable for energy crops [74]. Biomass and arable land are in fact expected to become a constrained resource with the increasing penetration of renewable energy in the system [74]. Use of biomass resources for energy purposes will cause competition between energy generation and other uses (e.g., feeding, bedding, ploughing back to fields etc.), suggesting that a zero burden assumption is unlikely to be correct, in particular, for a long-term perspective. In this context, the system boundary definition has a large influence on the results because biomass provision accounts for on average $71 \%$ of the emissions from biomass systems (see Section 5.4). Such a value is, however, associated with large variability and uncertainty, depending on whether the indirect land use change (ILUC) effects of energy crops cultivation are included. Despite being believed to have the largest contribution of GHG in the life cycle of biofuels [72], ILUC effects are not often included systematically in LCA and are, in any case, associated with large uncertainty, as their magnitude remains partly unclear and is highly disputed [75].

\subsection{Multi-input/output systems}

In Section 4, emissions factors for electricity generation were presented for single technologies. However, electricity is often produced in multi-input and/or multi-output systems. A cocombustion power plant is an example of a multi-input system in which a mix of fuels (e.g., coalstraw, waste-coal, etc.) is used as feedstock for the process. Examples of multi-output systems are combined heat and power plants (CHP) and biorefineries. In CHP plants, district heating and/or steam are important co-products of electricity generation. District heating is often utilized for household heating in cold climates (e.g., $46 \%$ of the heat demand in Denmark is covered by district heating [76]), whereas steam can be used in industrial applications for heating purposes. In integrated biorefinery systems, biomass is converted to a range of energy carriers (e.g., electricity, biogas and bioethanol) and chemicals. Biorefineries are developed to be flexible and are thus capable of adjusting production according to the demand of products [77].

Determination of emission factors for electricity generation from multi-stream systems involves allocation of emissions, which makes results uncertain because they are highly influenced by the chosen allocation criteria [78]. To avoid this allocation issue, in some cases, authors perform system expansion and provide emission factors based on the fuel mix (e.g., coal and biomass) [71]. However, both allocation and system expansion limit comparability among studies because of the subjective underlying assumption (e.g., allocation criteria) and the countless number of possible fuel mixes and operational conditions.

\subsection{Inventory data}

As previously illustrated, emission factors based on IOA can differ significantly from emission factors calculated via PCA. The reasons for this difference are twofold: 1 ) the two methods apply different allocation procedures because IOA uses economical parameters, whereas the allocation is often based on mass or energy (or exergy) for PCA; 2) because IOA is based on monetary data extrapolated at the country (or regional) level, it is not generally case specific (thus, local 
conditions are not taken into account), whereas PCA inventories are normally developed for individual processes. Finally, the most important aspect is most likely the cut-off criteria adopted when using the two methods. As the results in Section 4 also show, emission factors calculated using IOA are higher in most cases than PCA-based factors because of the smaller process chain cut-off practically achievable with IOA. In fact, the more complex the process, the greater the difference between the results from PCA- and IOA-based LCA studies [44]; due to its complexity, nuclear power is the technology most influenced by the choice of data source. For example, Sovacool [56] analyzed 19 studies on electricity from nuclear power and found emission factors varying in from 1-288 $\mathrm{g} / \mathrm{kWh}$ depending on several factors, with the lower values corresponding to PCA data and the higher values corresponding to IOA data. In particular, two studies from Storm van Leeuwem [79] and Dones [3,80] reported emissions factors differing by one order of magnitude: $110-170 \mathrm{~g} / \mathrm{kWh}[79]$ with IOA and 7.6-14 g/kWh [3,80] with PCA. It may be speculated that IOA significantly overestimates the emission factors for nuclear power mainly because of the high-tech components used in the nuclear industry. For example, if the price of high-quality steel used at a nuclear power plant is double the average price of steel, the IOA approach would provide for $1 \mathrm{~kg}$ of such steel to include emissions corresponding to $2 \mathrm{~kg}$ of average steel, thereby leading to overestimation of the emissions in most cases [34].

The abovementioned aspects and related assumptions all could have a great influence on the estimation of emission factors and the subsequent outcomes of comparative studies. For example, GHG emission factors from wind energy for electricity generation are on the order of 3-41 g $\mathrm{CO}_{2} / \mathrm{kWh}$ (see Section 4.8), with almost no difference between IOA and PCA methods. When comparing this range with nuclear power (i.e., 110-170 $\mathrm{g} \mathrm{CO}_{2} / \mathrm{kWh}$ with $1 \mathrm{OA}$, 7.6-14 $\mathrm{g} \mathrm{CO}_{2} / \mathrm{kWh}$ with P(A), the choice of the methodology could thus reverse the results of the comparison.

\subsection{Functional unit and comparability}

The functional unit of an assessment plays an extremely important (and sometimes overlooked) role in relation to comparability, even within a single study. When performing LCA of energy systems, the functioning of the power plant under assessment needs to be taken into consideration in the assessment; to be comparable within the same functional unit, individual technologies must provide the exact same service to the system. An example of incomparability is base-load (or load-following) electricity generation based on coal (with an emission factor of 660$1050 \mathrm{~g} \mathrm{CO}_{2} / \mathrm{kWh}$, Table 2), which does not provide the same service as a gas turbine covering peak-load electricity demand (with an emission factor of $610-850 \mathrm{~g} \mathrm{CO}_{2} / \mathrm{kWh}$, Table 2). Another example is the comparison between base-load and intermittent technologies, such as wind power. In this case, the incomparability is due to the different "reliability of supply" of the two systems. Two authors $[46,55]$ proposed a solution to overcome this discrepancy by modeling the intermittent source with a storage system so that the services provided by the two alternatives are technically identical. Examples of other specific services provided by individual technologies that should be addressed in the functional unit are irrigation and flood control, regulation, voltage control, system black-start capability, and operating reserve $[19,33,46]$.

\subsection{Additional impacts to be considered}

An LCA should, in principle, include all relevant potential environmental impacts related to the fulfillment of the functional unit [23]. Current guidelines [20] do not specify a minimum number of impact categories to be included or a preferred methodology, but rather suggest typical impact 
categories [81]. In Section 5.1, the importance of considering acidification and eutrophication in addition to global warming was addressed. Other environmental burdens that could be relevant to electricity technologies, but not often included in an LCA, are noise (could be relevant for wind power, for example), odor (e.g., biomass), risk associated with long-term storage of nuclear waste, alteration of ecosystems and natural habitats (e.g., biomass and hydroelectric power), induced risk of seismicity and subsidence (e.g., extraction of fossil fuels and hydroelectric power) [19], water consumption and scarcity (e.g., biomass and hydroelectric power), and resource scarcity (e.g., rare earth metals in photovoltaic).

\section{Conclusions}

Emission data for $\mathrm{GHG}, \mathrm{NO}_{\mathrm{x}}$ and $\mathrm{SO}_{2}$ were evaluated based on a critical review of 167 LCA case studies of important electricity generation technologies. Significant variations in the results were found, even for the same individual technology. A range of both technological and methodological differences were identified and evaluated with respect to their importance for LCA results. The most important technological aspects were, for fossil fuel technologies, the energy recovery efficiency and the flue gas cleaning system; for nuclear and renewable technologies, the electricity mix used during both the manufacturing and the installation phase; for biomass-based systems, the type, quality and origin of feedstock, as well as the amount and type of co-products. From an LCA methodological perspective, the most critical aspects affecting the coherence and transparency of the results were the functional unit definition (i.e., the service of the system under assessment), the LCA method employed (e.g., IOA, PCA and hybrid), and the allocation principle and/or system boundary expansions when used. For biomass-based electricity generation, assumptions concerning the upstream land-use-related emissions (both direct and indirect) and assumptions about biomass being a constrained resource significantly affected the results. The incorrect or inappropriate use of emission data and LCA results may generate the wrong conclusions. It is recommended that future research involving LCA modeling of electricity generation include clear statements of data applicability and methodological limitations, thereby significantly increasing the transparency and usability of the results obtained from LCA. This paper provides a basis for making the necessary choices regarding emission data, technological scopes, and methodological approach.

\section{Appendix A. Supplementary material}

Supplementary data associated with this article, including (1) an extensive discussion of the criteria used to select the studies considered in the present review, (2) tables containing emission factors for each study included in the review, and (3) the relationship between plant efficiency and direct emissions of $\mathrm{NO}_{\mathrm{x}}$ and $\mathrm{SO}_{2}$ for coal, lignite, natural gas and oil, can be found in the online version at XXXXXXX. 


\section{References}

[1] International Energy Agency, Electricity Information 2010, 2010.

[2] Bergerson J, Lave L. Life cycle analysis of power generation systems, Encyclopaedia of Energy. 3 (2004) 635-645.

[3] Dones R, Heck R, Hirschberg S. Greenhouse Gas Emissions from Energy Systems, Comparison and Overview, Encyclopaedia of Energy. 3 (2004) 77-95.

[4] Varun, Bhat IK, Ravi Prakash. LCA of renewable energy for electricity generation systems- A review, Renewable and Sustainable Energy Reviews. 13 (2009) 1067-1073.

[5] Sims REH, Schock RN, Adegbululgbe A, Fenhann J, Konstantinaviciute I, Moomaw W, Nimir HB, Schlamadinger B, Torres-Martinez J, Turner C, Uchiyama Y, Vuori SVJ, Wamukonya N, Zhang X. Energy supply. In Climate Change 2007: Mitigation, Fourth Assessment Report of the Intergovernmental Panel on Climate Change. (2007).

[6] Lund C, Biswas W. A Review of the Application of Lifecycle Analysis to Renewable Energy Systems, Bulletin of Science, Technology \& Society. 28 (2008) 200-209.

[7] Van De Vate J. Comparison of energy sources in terms of their full energy chain emission factors of greenhouse gases, Energy Policy. 25 (1997) 1-6.

[8] Weisser D. A guide to life-cycle greenhouse gas (GHG) emissions from electric supply technologies, Energy. 32 (2007) 1543-1559.

[9] Tonini D, Astrup T. LCA of biomass-based energy systems: A case study for Denmark, Applied Energy. 99 (2012) 234-246.

[10] Finnveden G, Ekvall T. Life-cycle assessment as a decision-support tool - the case of recycling versus incineration of paper, Resources, Conservation and Recycling. 24 (1998) 235-256.

[11] Clarke L, Edmonds J, Jacoby J, Pitcher H, Reilly J, Richels R, Parson E, Burkett V, Fisher-Vanden K, Keith D, Mearns L, Rosenzweig C, Webster M. CCSP, 2007: Scenarios of Greenhouse Gas Emissions and Atmospheric Concentrations (Part A) and Review of Integrated Scenario Development and Application (Part B). A Report by the U.S. Climate Change Science Program and the Subcommittee on Global Change Res, Washington, DC., USA, 2007.

[12] Boldrin A, Andersen JK, Christensen TH. Environmental assessment of garden waste management in the Municipality of Aarhus, Denmark., Waste Management. 31 (2011) 1560-9.

[13] Finnveden G, Hauschild MZ, Ekvall T, Guinée J, Heijungs R, Hellweg S, Koehler A, Pennington D, Suh S. Recent developments in Life Cycle Assessment., Journal of Environmental Management. 91 (2009) 1-21.

[14] Weidema BP, Thrane M, Christensen P, Schmidt J, Løkke S. Carbon Footprint, Journal of Industrial Ecology. 12 (2008) 3-6.

[15] Spadaro JV, Langlois L, Hamilton B. GREENHOUSE GAS EMISSIONS OF ELECTRICITY GENERATION CHAINS - Assessing the difference, IAEA BULLETIN. 42 (2000) 2.

[16] Odeh N, Cockerill T. Life cycle analysis of UK coal fired power plants, Energy Conversion and Management. 49 (2008) 212-220. 
[17] Ito $\mathrm{M}$, Kato $\mathrm{K}$, Komoto $\mathrm{K}$, Kichimi T, Kurokawa K. A comparative study on cost and life-cycle analysis for $100 \mathrm{MW}$ very large-scale PV (VLS-PV) systems in deserts using $\mathrm{m}-\mathrm{Si}$, a-Si, CdTe, and CIS modules, Progress in Photovoltaics: Research and Applications. 16 (2008) 17-30.

[18] Meier PJ. Life-Cycle Assessment of Electricity Generation Systems and Applications for Climate Change Policy Analysis, 2002.

[19] Edenhofer O, Pichs-Madruga R, Sokona Y, Seyboth K, Matschoss P, Kadner S, Zwickel T, Eickemeier P, Hansen G, Schlömer S, von Stechow C. IPCC Special Report on Renewable Energy Sources and Climate Change Mitigation, 2011.

[20] ISO, EN ISO 14040 Environmental management - Life cycle assessment - Principles and framework, 2006.

[21] European Commission - Joint Research Centre - Institute for Environment and Sustainability, EC-JRC, International Reference Life Cycle Data System (ILCD) Handbook - General guide for Life Cycle Assessment - Detailed guidance, Luxembourg, Publications Office of the European Union, 2010.

[22] World Wind Energy Association WWEA, World Wind Energy Report 2009, Bonn, Germany, 2009.

[23] ISO, EN ISO 14044 Environmental management - Life cycle assessment - Requirements and guidelines, 2006.

[24] Whitaker M, Heath GA, O'Donoughue P, Vorum M. Life Cycle Greenhouse Gas Emissions of Coal-Fired Electricity Generation: Systematic Review and Harmonization, Journal of Industrial Ecology. 16 (2012).

[25] Warner ES, Heath GA. Life Cycle Greenhouse Gas Emissions of Nuclear Electricity Generation: Systematic Review and Harmonization, Journal of Industrial Ecology. 16 (2012).

[26] Kim HC, Fthenakis V, Choi JK, Turney DE, Life Cycle Greenhouse Gas Emissions of Thin-film Photovoltaic Electricity Generation, Journal of Industrial Ecology. 16 (2012) no-no.

[27] Hsu DD, O'Donoughue P, Fthenakis V, Heath GA, Kim HC, P. Sawyer, Choi JK, Turney DE. Life Cycle Greenhouse Gas Emissions of Crystalline Silicon Photovoltaic Electricity Generation: Systematic Review and Harmonization, Journal of Industrial Ecology. 16 (2012).

[28] Dolan SL, Heath GA. Life Cycle Greenhouse Gas Emissions of Utility-Scale Wind Power: Systematic Review and Harmonization, Journal of Industrial Ecology. 16 (2012).

[29] Padey P, Blanc I, Le Boulch D, Xiusheng Z. A Simplified Life Cycle Approach for Assessing Greenhouse Gas Emissions of Wind Electricity, Journal of Industrial Ecology. 16 (2012) S28S38.

[30] Hendrickson C, Horvath A, Joshi S, Lave L. Economic input-output models for environmental life-cycle assessment, Environmental Science \& Technology. 32 (1998) 184.

[31] Joshi S. Product Environmental Life-Cycle Assessment Using Input-Output Techniques, Journal of Industrial Ecology. 3 (1999) 95-120.

[32] Meier P, Wilson $P$, Kulcinski G, Denholm P, US electric industry response to carbon constraint: a life-cycle assessment of supply side alternatives, Energy Policy. 33 (2005) 1099-1108. 
[33] World Energy Council, Comparison of energy systems using Life Cycle Assessment, London, UK, 2004.

[34] Weidema BP, Ekvall T, Heijungs R. Guidelines for application of deepened and broadened LCA - Deliverable D18 of work package 5 of the CALCAS project, 2009.

[35] Suh S, Huppes G. Methods for Life Cycle Inventory of a product, Journal of Cleaner Production. 13 (2005) 687-697.

[36] Heijungs R, Koning A, Suh S, Huppes G. Toward an Information Tool for Integrated Product Policy: Requirements for Data and Computation, Journal of Industrial Ecology. 10 (2006) 147158.

[37] Wiedmann TO, Suh S, Feng K, Lenzen M, Acquaye A, Scott K, Barrett JR. Application of hybrid life cycle approaches to emerging energy technologies - The case of wind power in the UK., Environmental Science \& Technology. 45 (2011) 5900-7.

[38] European Environment Agency, Emissions (CO2, SO2, NOx) from public electricity and heat production - explanatory indicators (ENER 009) - Assessment published Aug 2011 -, (2011).

[39] European Environment Agency, Ammonia (NH3) emissions (APE 003) - Assessment published Oct 2010, (2010).

[40] International Energy Agency, World Energy Outlook 2010, 2010.

[41] Spath PL, Mann MK, Kerr DR. Life Cycle Assessment of Coal-fired Power Production, 1999.

[42] May J, Brennan D. Life cycle assessment of Australian fossil energy options, Process Safety and Environmental Protection. 81 (2003) 317-330.

[43] May J, Brennan D. Life Cycle Assessment of Australian Fossil Energy Options - ERRATUM, Process Safety and Environmental Protection. 82 (2008) 9575820-9575820.

[44] Dones R, Heck T, Bauer C, Hirschberg S, Bickel P, Preiss P, Panis LI, De Vlieger I. ExternE Externalities of Energy: Extension of Accounting Framework and Policy Applications New energy technologies, 2005.

[45] Cameco Corporation, Comparison of Lifecycle Greenhouse Gas Emissions of Various Electricity Generation Sources, 2010.

[46] Gagnon L, Bélanger C, Uchiyama Y. Life-cycle assessment of electricity generation options: The status of research in year 2001, Energy Policy. 30 (2002) 1267-1278.

[47] Nomura N. Life-cycle emission of oxidic gases from power-generation systems, Applied Energy. 68 (2001) 215-227.

[48] European Commission, ExternE Externalities of Energy - Vol XX: National Implementation, 1999.

[49] Harrison MR, Shires TM, Wessels JK, Cowgill RM. Methane Emissions from the Natural Gas Industry, National Risk Management Research Laboratory. Research Triangle Park, NC., 1997.

[50] U.S. Department of Energy - Energy Information Administration, Natural Gas 1998: Issues and Trends, Washington, DC., USA, 1999. 
[51] Skone T, James R. Life Cycle Analysis: Natural Gas Combined Cycle (NGCC) Power Plant, 2010.

[52] European Commission, ExternE - Externalities of energy: vol.4 - Oil and Gas, 1995.

[53] Hondo $\mathrm{H}$. Life cycle GHG emission analysis of power generation systems: Japanese case, Energy. 30 (2005) 2042-2056.

[54] Lenzen M. Life cycle energy and greenhouse gas emissions of nuclear energy: A review, Energy Conversion and Management. 49 (2008) 2178-2199.

[55] Fthenakis V, Kim HC. Greenhouse-gas emissions from solar electric- and nuclear power: A lifecycle study, Energy Policy. 35 (2007) 2549-2557.

[56] Sovacool B. Valuing the greenhouse gas emissions from nuclear power: A critical survey, Energy Policy. 36 (2008) 2950-2963.

[57] Gagnon L. Greenhouse gas emissions from hydropower The state of research in 1996, Energy Policy. 25 (1997) 7-13.

[58] Evans A, Strezov V, Evans TJ. Assessment of sustainability indicators for renewable energy technologies, Renewable and Sustainable Energy Reviews. 13 (2009) 1082-1088.

[59] Cherubini F, Bird ND, Cowie A, Jungmeier G, Schlamadinger B, Woess-Gallasch S. Energy- and greenhouse gas-based LCA of biofuel and bioenergy systems: Key issues, ranges and recommendations, Resources, Conservation and Recycling. 53 (2009) 434-447.

[60] Lerche H, Gagnon L, Saur I, Jørgen O. Life cycle greenhouse gas (GHG) emissions from the generation of wind and hydro power, Renewable and Sustainable Energy Reviews. 15 (2011) 3417-3422.

[61] Fthenakis V, Alsema E. Photovoltaics Energy Payback Times, Greenhouse Gas Emissions and External Costs: 2004-early 2005 Status, Energy. (2006) 275-280.

[62] Krauter S, Ruther R. Considerations for the calculation of greenhouse gas reduction by photovoltaic solar energy, Renewable Energy. 29 (2004) 345-355.

[63] Pehnt M. Dynamic life cycle assessment (LCA) of renewable energy technologies, Renewable Energy. 31 (2006) 55-71.

[64] Peng J, Lu L, Yang H. Review on life cycle assessment of energy payback and greenhouse gas emission of solar photovoltaic systems, Renewable and Sustainable Energy Reviews. 19 (2013) 255-274.

[65] Sherwani AF, Usmani JA. Life cycle assessment of solar PV based electricity generation systems: A review, Renewable and Sustainable Energy Reviews. 14 (2010) 540-544.

[66] Lenzen M. Energy and CO2 life-cycle analyses of wind turbines-review and applications, Renewable Energy. 26 (2002) 339-362.

[67] Khan F, Hawboldt K, Iqbal M. Life Cycle Analysis of wind-fuel cell integrated system, Renewable Energy. 30 (2005) 157-177.

[68] Arvesen A, Hertwich E.G. Assessing the life cycle environmental impacts of wind power: A review of present knowledge and research needs, Renewable and Sustainable Energy Reviews. 16 (2012) 5994-6006. 
[69] Christensen TH, Gentil E, Boldrin A, Larsen AW, Weidema BP, Hauschild M. C balance, carbon dioxide emissions and global warming potentials in LCA-modelling of waste management systems., Waste Management \& Research. 27 (2009) 707-15.

[70] IPCC, 2006 IPCC Guidelines for National Greenhouse Gas Inventories, 2006.

[71] Heller M. Life cycle energy and environmental benefits of generating electricity from willow biomass, Renewable Energy. 29 (2004) 1023-1042.

[72] Corti A. Biomass integrated gasification combined cycle with reduced $\mathrm{CO} 2$ emissions: Performance analysis and life cycle assessment (LCA), Energy. 29 (2004) 2109-2124.

[73] Spath PL, Mann MK. Life Cycle Assessment of a Natural Gas Combined-Cycle Power Generation System, 2000.

[74] Hedegaard K, Thyoe K, Wenzel H. Life cycle assessment of an advanced bioethanol technology in the perspective of constrained biomass availability., Environmental Science \& Technology. 42 (2008) 7992-9.

[75] Edwards R, Mulligan D, Marelli L. Indirect Land Use Change from increased biofuels demand, European Commission Joint Research Centre Institute for Energy, 2010.

[76] Dyrelund A, Lund H. Heat Plan Denmark 2010: a road map for implementing the EU directive on renewable energy, $\mathrm{HOT} / \mathrm{COOL}$ - International Magazine on District Heating and Cooling. 4 (2010) 11-13.

[77] Cherubini F. The biorefinery concept: Using biomass instead of oil for producing energy and chemicals, Energy Conversion and Management. 51 (2010) 1412-1421.

[78] Cherubini F, Strømman AH, Ulgiati S. Influence of allocation methods on the environmental performance of biorefinery products-A case study, Resources, Conservation and Recycling. 55 (2011) 1070-1077.

[79] Storm van Leeuwen JW, Smith P. Nuclear Power: The Energy Balance, Http://www.stormsmith.nl. (2007).

[80] Dones R, Bauer C, Bolliger R, Burger B, Heck T, Roder A, Tuchschmid M. Life Cycle Inventories of Energy Systems: Results for Current Systems in Switzerland and other UCTE Countries, Ecoinvent Report. 5 (2007).

[81] ISO, EN ISO 14047 Environmental management - Life cycle assessment - Examples of application of ISO 14042, 2006.

[82] Voorspools K. Energy content and indirect greenhouse gas emissions embedded in "emissionfree" power plants: results for the Low Countries, Applied Energy. 67 (2000) 307-330.

[83] Briem S, Blesl M, Fahl U, Ohl M. Chapter 10: Fossil gefeuelte Kraftwerke, in: Lebenszyklusanalysen Ausgewählter Zukünftiger Stromerzeugungstechniken [in German], Stuttgart, 2004: pp. 253-339.

[84] Pacca S, Horvath A. Greenhouse gas emissions from building and operating electric power plants in the Upper Colorado River Basin., Environmental Science \& Technology. 36 (2002) 3194-200. 
[85] Skone T, James R. Life Cycle Analysis: Existing Pulverized Coal (EXPC) Power Plant, 2010.

[86] U.S. Department of Energy, Life Cycle Analysis: Power Studies Compilation Report, 010.

[87] White S, Kulcinski G. Birth to death analysis of the energy payback ratio and $\mathrm{CO} 2$ gas emission rates from coal, fission, wind, and DT-fusion electrical power plants, Fusion Engineering and Design. 48 (2000) 473-481.

[88] Kannan R, Leong K, Osman R, Ho H. Life cycle energy, emissions and cost inventory of power generation technologies in Singapore, Renewable and Sustainable Energy Reviews. 11 (2007) 702-715.

[89] Vattenfall AB, Environmental Product Declaration Ringhals Nuclear Power Plant, 2010.

[90] Vattenfall AB, Environmental Product Declaration Forsmark Nuclear Power Plant, 2002.

[91] Axpo AG, Environmental Product Declaration Beznau Nuclear Power Plant, 2008.

[92] Hartmann D, Kaltschmitt M. Electricity generation from solid biomass via co-combustion with coal. Energy and emission balances from a German case study, Fuel and Energy Abstracts. 16 (1999) 395.

[93] Styles D, Jones M. Energy crops in Ireland: Quantifying the potential life-cycle greenhouse gas reductions of energy-crop electricity, Biomass and Bioenergy. 31 (2007) 759-772.

[94] Rafaschieri A, Rapaccini M, Manfrida G. Life Cycle Assessment of electricity production from poplar energy crops compared with conventional fossil fuels, Energy Conversion and Management. 40 (1999) 1477-1493.

[95] Sebastian F, Royo J, Gomez M. Cofiring versus biomass-fired power plants: GHG (Greenhouse Gases) emissions savings comparison by means of LCA (Life Cycle Assessment) methodology, Energy. 36 (2011) 2029-2037.

[96] Mann MK, Spath PL. Life Cycle Assessment of a Biomass Gasification Combined-Cycle System, 1997.

[97] Rule BM, Worth ZJ, Boyle C. Comparison of life cycle carbon dioxide emissions and embodied energy in four renewable electricity generation technologies in New Zealand., Environmental Science \& Technology. 43 (2009) 6406-13.

[98] Vattenfall AB, Environmental Product Declaration Vattenfall Nordic Hydropower, 2008.

[99] Axpo AG, Environmental Product Declaration Wildegg-Brugg run-of-river Power Plant, 2010.

[100] Elaqua AG, Environmental Product Declaration Au-schönenberg Small-scale Hydro Power Plant, 2011.

[101] Alsema E. Energy pay-back time and $\mathrm{CO} 2$ emissions of PV systems, Progress in Photovoltaics: Research and Applications. 8 (2000) 17-25.

[102] Gagnon L, Bélanger C. Adding wind energy to hydropower, Energy Policy. 30 (2002) 12791284.

[103] Schleisner L. Life cycle assessment of a wind farm and related externalities, Renewable Energy. 20 (2000) 279-288. 
[104] Vestas Wind Systems A/S, Life cycle assessment of offshore and onshore sited wind power plants based on Vestas V90-3.0 MW turbines, Randers, Denmark, 2006.

[105] Vattenfall AB, Environmental Product Declaration Vattenfall Wind Power, 2010.

[106] Ambiente Italia srl, Environmental Product Declaration ENEL Wind Power Plant Sclafani Bagni 1, 2004.

[107] European Commission, ExternE - Externalities of energy: vol.6 - Wind and Hydro, 1995. 